\title{
Retrofitting of SCC Deep Beams With Circular Openings Using CFRP
}

\author{
Nabeel A. Al-Bayati ${ }^{\mathrm{a}}$,Dhiyaa H. Mohammed ${ }^{\mathrm{b}}$, Nawfal A. Abdul Jabbar ${ }^{\mathrm{c}^{*}}$ \\ aAshur University College, Baghdad, Iraq, Nabeel.al-bayati@au.edu.iq \\ ${ }^{\mathrm{b}}$ Civil Engineering Department, University of Technology, Baghdad, Iraq, 40041@uotechnology.edu.iq \\ ${ }^{c}$ Civil Engineering Department, University of Technology, Baghdad, Iraq, engineer_nawfal@yahoo.com \\ *Corresponding author.
}

Submitted:26/02/2019

Accepted: 18/04/2019

Published: 25/07/2021

\section{K E Y W O R D S}

CFRP, Circular openings, Deep beams, Retrofitting, Selfcompacting concrete.

\begin{abstract}
A B S T R A C T
The main objectives of this study are: encouraging the production and use of self-compacting concrete, use of materials which are lightweight, easy to use, and highly efficient in the retrofitting of reinforced concrete buildings. Six deep beams specimens ( $L=$ length of $1400 \mathrm{~mm}, h=$ height of $400 \mathrm{~mm}$, and $b=$ width of $150 \mathrm{~mm})$ were cast using self-compacting concrete. The location of the openings is in the middle of assumed load path. Five patterns were adopted to arrange carbon fiber reinforced polymer (CFRP) strips. The cylinder compressive strength of the concrete was approximately equal for all beams and was about (44 MPa) at 28 days age. All the beams have the same steel reinforcement for shear and flexure. There have been many tests for fresh and hardened concrete. The reinforced concrete deep beams were tested up to (60\%) of the ultimate load of control beams to simulate degree of damage, and then released the load. After that, the beams were retrofitted using (CFRP) strips, and then the beams were tested to failure. The study was focused on determining the vertical mid-span deflection, ultimate load, the load that causes first shear and flexural cracks, and mode of failure. The results showed that, the best increase in the ultimate failure load was (27.27\%) and achieved using the inclined strips pattern and the pattern of vertical and horizontal strips together. Reduction in the deflection values for the retrofitted beams compared to the control beam by about (12-13\%) due to restrictions imposed by CFRP strips and the epoxy.
\end{abstract}

\footnotetext{
How to cite this article: N. A. Al-Bayati, D. H., Mohammed, and N. A. Abdul Jabbar, "Retrofitting of SCC Deep Beams With Circular Openings Using CFRP" Engineering and Technology Journal, Vol. 39, No. 07, pp. 1092-1104, 2021.

DOI: https://doi.org/10.30684/etj.v39i7.74

This is an open access article under the CC BY 4.0 license http://creativecommons.org/licenses/by/4.0
} 


\section{INTRODUCTION}

Deep beams are structural elements loaded as simple beams in which a significant amount of the load is carried to the supports by a compression force combining the load and the reaction. According to ACI 318M-14 Code [1], deep beams have either a clear span to depth ratio less than or equal 4.0 $(\mathrm{Ln} \leq 4.0 \mathrm{~h})$ or shear span to depth ratio $(\mathrm{a} / \mathrm{h})$ less than 2.0 for concentrated load and less than 4.0 for distributed load. Self-consolidating concrete (SCC) is highly flow able, non-segregating concrete that can spread into place, fill the formwork, and encapsulate the reinforcement without any mechanical consolidation [2-3].

The typical remediation for such conditions includes the installation of structural steel frames and other elements, to provide additional strength to support the existing concrete. However, carbon fiber reinforced polymer (CFRP) is an alternative material that is able to provide strengthening effects, with much lower weight. CFRP is a material composed of carbon fibers as a first material and a polymer resin (sometimes called the epoxy paste) as a second material. Careful attention to proper surface preparation must be taken, including a primer coating to penetrate the substrate and enhance bonding ability. The openings within the beams have two effects: the positive effects of circular web openings to be used in passing pipeline services and the reduction from the weight of the beam and the negative effects such as the amount of decrease in the strength of the beam when it contains circular web openings or when increasing the diameter of the circular openings. Five patterns of CFRP strips were adopted to retrofit five deep beams. The objective of the present paper is to investigate which of the five patterns of arrangements and distribution of carbon fiber strips gives the highest amount of increase in the ultimate failure load after retrofitted process.

\section{LITERATURE REVIEW}

Many researchers investigated the effective of externally bonded FRP system as an external reinforcement to strengthening RC deep beams.

"Yang et al." [4]. The results were summarized from tests on 23 high strength concrete deep beams without and with openings. The specimens were simply supported beams with simple length of $2400 \mathrm{~mm}$, depth of $600 \mathrm{~mm}$ and width of $160 \mathrm{~mm}$. The web rectangular openings were placed to intercept the load path. The variables considered in this study were the compressive strength of concrete, the openings dimensions, and $\mathrm{a} / \mathrm{h}$ ratios. The results revealed that, the ultimate failure load sand inclined cracks of the tested deep beams were greatly linked to the inclination angle from the plane connecting edges of the opening sand the support. Moreover, it was found that the influence of, high strength concrete in deep beams with web openings, on the ultimate capacity was lower.

"Khudair and Atea" [5]. The results were summarized from experimental study on eleven simply supported deep beams. The beams were casted using self-consolidating concrete then strengthened by CFRP strips. The shear span to the effective depth (a/d) ratio was 2.0. The dimensions for all beams were width of $175 \mathrm{~mm}$, depth of $300 \mathrm{~mm}$, and total length of $1600 \mathrm{~mm}$. Parameters adopted were CFRP strips direction (vertical straight, horizontal \& vertical, and inclined $45^{\circ}$ ), shape and length of CFRP strips (totally wrapped, U- shaped wrapped, and sides wrapped), and two values of spacing between CFRP strips (20 and $50 \mathrm{~mm}$ ). The result revealed that the CFRP strips helped to improve the ultimate failure load by $33 \%$ approximately and their use resulted in cracks width reduction by nearly $45 \%$ compared with the reference beam. Furthermore, the deflection of strengthened beams was clearly lower than the deflection of the non-strengthened reference beam at the same applied load value. Shape, length, width, directions, spacing, and arrangements, of CFRP strips played a key role in improving ultimate failure load and reducing the deflection and cracks width for strengthened beam. Finally, it was noted that due to de-bonding of CFRP strips the failure mode for all examined beams was diagonal shear crack.

\section{Experimental Program}

Six deep beams were tested under symmetrical two points of load as a simply support beam. All the deep beams had the same dimensions (length of $1400 \mathrm{~mm}$, height of $400 \mathrm{~mm}$, and width of $150 \mathrm{~mm})$ as shown in Figure 1. Also, all the beams had same shear span to the effective depth $(\mathrm{a} / \mathrm{d})$ ratio which equal to 1 . Each beam provided by three deformed steel bars diameter of $16 \mathrm{~mm}$ (3Ø16 $\mathrm{mm}$ as a main tension reinforcement); this ratio is nearby the maximum allowable ratio of 
flexural reinforcement and deformed steel wires with diameter of $6 \mathrm{~mm}$ were used for shear reinforcement vertically as closed stirrups and horizontally as skin reinforcement with spacing each $70 \mathrm{~mm} \mathrm{c} / \mathrm{c}$, this ratio is slightly more than the minimum ratio allowed by ACI 318M-14 [1] Code requirements for shear reinforcement of deep beam.

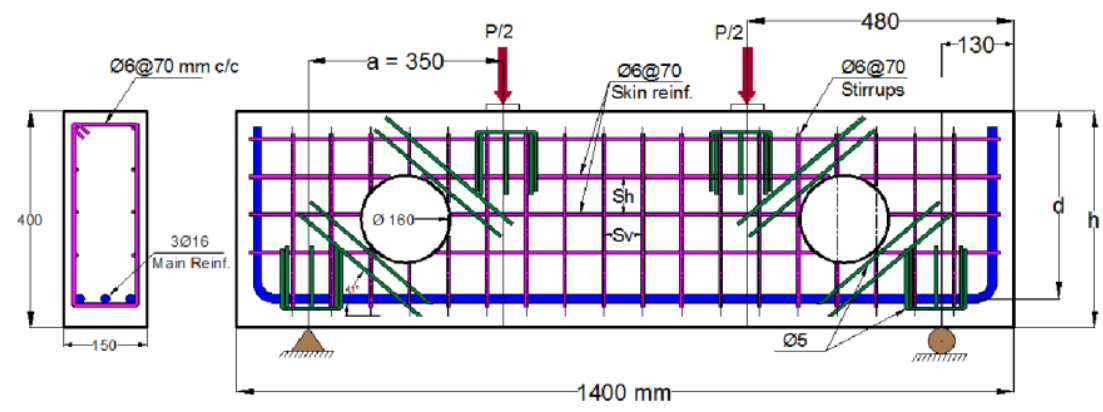

Figure 1: Details of the deep beam reinforcement

One deep beam specimen used as a control beam without retrofitting and five deep beams were retrofitted using externally bonded carbon fiber reinforced polymer (CFRP) strips. The beams were tested up to $(60 \%)$ of the ultimate load for the control beams to simulate the degree of damage [6-8]. After that, they are retrofitted using CFRP strips with various arrangements and distributions and then they were tested to failure.

Five patterns of carbon fiber reinforced polymer (CFRP) strips arrangement were adopted in the retrofitting of five deep beams to examine their effect on the behavior and performance of the deep beam after retrofitting process or in other words their effect on the ultimate failure load, vertical midspan deflection, shear and flexural cracks, and mode of failure. The patterns are illustrated in Table I and Figure 2.

TABLE I: Deep beam specimen's details

\begin{tabular}{ccc}
\hline \hline Specimen symbols & Retrofitting details & Pre-loading ratio \\
\hline $\boldsymbol{B} 1-\boldsymbol{C o n t r o l}$ & None & $100 \%$ \\
\hline $\boldsymbol{B} 1-\boldsymbol{R}-\boldsymbol{V}$ & Two vertical U- shape strips & $60 \%$ \\
\hline $\boldsymbol{B} 2-\boldsymbol{R}-\boldsymbol{H}$ & Two horizontal strips & $60 \%$ \\
\hline $\boldsymbol{B} 3-\boldsymbol{R}-\boldsymbol{V} \boldsymbol{H}$ & Two vertical U- shape strips and Two horizontal strips & $60 \%$ \\
\hline $\boldsymbol{B} 4-\boldsymbol{R}-\boldsymbol{I}$ & Two inclined strips (orthogonal on load path) & $60 \%$ \\
\hline $\boldsymbol{B} 5-\boldsymbol{R}-\boldsymbol{S} \boldsymbol{S}$ & Shear span covered with (CFRP) & $60 \%$ \\
\hline
\end{tabular}

It is worth mentioning that, width of the CFRP strips is $100 \mathrm{~mm}$. The beams were symbolized by three characters: the first one refers to (Beam) followed by number representing the sequence of the deep beam which extends from 1 to 5 , the second part contains letter (R) which represents retrofitting, and refers to the type the retrofitting

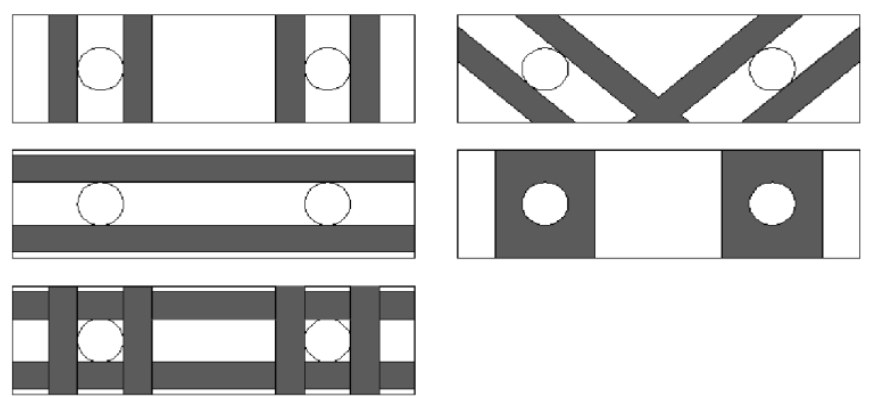
the third one and direction of CFRP strips.

Figure 2: The five adopted patterns in this study 


\section{乏. MAterials}

\section{Cement}

Ordinary Portland cement (Type I) has been used in this study. Table II shows the tests results of the physical properties of cement and tests results of the chemical properties are presented in Table III. Tests were conducted by the National Center for Construction Laboratories. Tests results conform to Iraqi Standards Specifications IQS No.5/1984 [9].

\section{Coarse Aggregate}

Crushed gravel with a maximum size of $(14 \mathrm{~mm})$ was used in this study. The results of sieve analysis test of gravel gradation are presented in Table IV. While, Table V shows the tests results for the physical and chemical properties of gravel. The results showed that the coarse aggregate meets the requirements of the Iraqi Standard Specification IQS No.45/1984 [10] in terms of gradation and sulfate content.

\section{Fine Aggregate}

Natural sand was used in all stages of experimental works. The results of sieve analysis test of sand gradation are presented in Table VI. While, Table VII shows the tests results for the physical and chemical properties of sand. The results showed that the fine aggregate meets the requirements of the Iraqi Standard Specification IQS No.45/1984 [10] in terms of sulfate content and gradation (within the gradation zone 2).

\section{Silica Fume}

Microsilica named MegaAddMS(D) produced by (CONMIX LTD.) company for Construction Chemicals in Al Sharjah, United Arab Emirates was used throughout this study as a mineral admixture to improve both of the fresh and hardened properties of SCC.

\section{V.High Performance Super plasticizer Concrete Admixture}

(Sika ${ }^{\circledR}$ ViscoCrete-5930) was used in all stages of experimental work. It is a third generation super plasticizer for concrete and mortar and meets requirements for super plasticizer according to ASTM C494/C494M-15 [11] types G and F.

The most important features of (Sika ${ }^{\circledR}$ ViscoCrete-5930) are High water reduction, excellent flow ability, and high early strength.

\section{VI.Carbon Fiber Reinforcement Polymer (CFRP)}

Unidirectional Carbon Fiber Wrap manufactured by Sika company (Korea), named (SIKAWRAP ${ }^{\circledR}-300 \mathrm{C}$ ) having width of $500 \mathrm{~mm}$ and thickness of $0.166 \mathrm{~mm}$ was used in this study.

\section{VII.Bonding Materials}

Sikadur ${ }^{\circledR}-330$ is a two parts, solvent free, thixotropic epoxy based impregnating resin /adhesive. This material consists of two parts, part (A) which is resin paste with white color, and part (B) which is hardener paste with grey color. It is worth mentioning that, the mixing ratio of the two compounds is 1:4 by weight and the color of the epoxy after mixing the two compounds together is light grey.

\section{VIII.Steel Reinforcement}

According to the ASTM A370-14 [12] and using three samples of each diameter of rebar, tensile tests were carried out to obtain the tensile yield strength $\left(\mathrm{f}_{\mathrm{y}}\right)$, tensile strength $\left(\mathrm{f}_{\mathrm{u}}\right)$ and percentage of elongation. The tests were carried out at the Department of Materials Engineering laboratories /University of Technology. Table VIII shows that the deformed steel wire of diameter $6 \mathrm{~mm}$ meets the requirements of ASTM A1064/A1064M-14 [13]. The deformed steel bars diameter of $16 \mathrm{~mm}$ meets also the requirements of ASTM A615/615M-14 [14] for grade $414 \mathrm{MPa}$.

\section{CONCRETe MiXes}

According to The European Guidelines for Self-Compacting Concrete 2005 [2], and the requirements of EFNARC [15], six attempts have been made to produce self-consolidating concrete 
to meet requirements or the characteristics of fresh SCC. The main characteristics of fresh SCC are segregation resistance, filling ability, time of flow or viscosity, and filling ability. The mixture is made up of \{cement: fine aggregate: coarse aggregate: silica fume\} where the percentage was 1:1.927:1.406:0.094 by weight and with water to cementitious ratio $\mathrm{w} / \mathrm{p}(\mathrm{p}=$ silica fume + cement $)$ was $0.352(185 /(45+480))$. Table IX shows the mix proportion which was successful in all tests of fresh SCC and was used throughout this study. The tests (L-box, Slump Flow, T500, Sieve Segregation, V-funnel, and J-ring) were performed after the completion of the mixing process to make sure that it meets the characteristics of the fresh SCC. Table X illustrates the results of the tests.

TABLE II: Tests results of the physical properties of cement

\begin{tabular}{lccc}
\hline \multicolumn{1}{c}{ Physical Properties } & Units & $\begin{array}{c}\text { Test } \\
\text { Result }\end{array}$ & IQS5/1984 ${ }^{[9]}$ \\
\hline Fineness using Blaine air permeability apparatus & $\mathrm{m}^{2} / \mathrm{kg}$ & 337 & 230 (min.) \\
\hline Soundness using autoclave method & $\%$ & 0.23 & 0.8 (max.) \\
\hline $\begin{array}{l}\text { Setting Time (Vicat's Method) } \\
\text { Initial time }\end{array}$ & Minutes & $1: 45$ & $00: 45$ (min.) \\
Final time & Minutes & $7: 40$ & $10: 00$ (max.) \\
\hline $\begin{array}{l}\text { Compressive strength for cement paste } \\
\text { cube mold (50 mm) at: }\end{array}$ & & & \\
3 days & $\mathrm{MPa}$ & 19.6 & $\begin{array}{c}\text { Minimum15 MPa } \\
\text { 7 days }\end{array}$ \\
\hline
\end{tabular}

TABLE III: Tests results of the chemical properties of cement

\begin{tabular}{lccc}
\hline \hline Compound composition & $\begin{array}{c}\text { Chemical } \\
\text { composition }\end{array}$ & $\begin{array}{c}\text { Test Result } \\
\text { \% by weight }\end{array}$ & IQS 5/1984 \\
\hline Lime & $\mathrm{CaO}$ & 62.41 & - \\
\hline Silica & $\mathrm{SiO} 2$ & 22.36 & - \\
\hline Alumina & $\mathrm{A} 2 \mathrm{O} 3$ & 4.19 & - \\
\hline Iron Oxide & $\mathrm{Fe} 2 \mathrm{O} 3$ & 3.96 & - \\
\hline Magnesia Oxide & $\mathrm{MgO}$ & 1.82 & max. \\
\hline Sulfate & $\mathrm{SO}$ & 2.41 & 2.8 max. \\
\hline Loss on ignition & $\mathrm{L} . \mathrm{O} . \mathrm{I}$ & 2.67 & 1.5 max. \\
\hline Insoluble residue & $\mathrm{I} . \mathrm{R}$ & 0.44 & $0.66-1.02$ \\
\hline Lime saturation factor & $\mathrm{L} . \mathrm{S} . \mathrm{F}$ & 0.86 & - \\
\hline Dicalcium Silicate & $\mathrm{C} 2 \mathrm{~S}$ & 25.41 & - \\
\hline Tricalcium Silicate & $\mathrm{C} 3 \mathrm{~S}$ & 48.17 & - \\
\hline Tricalcium Aluminate & $\mathrm{C} 3 \mathrm{~A}$ & 5.47 & - \\
\hline TetracalciumAlumminoferrite & $\mathrm{C} 4 \mathrm{AF}$ & 10.53 & \\
\hline
\end{tabular}

TABLE IV: Coarse aggregate Gradation*

\begin{tabular}{ccc}
\hline \hline Sieve Size(mm) & \% passing by weight & IQS 45/1984 $^{[\mathbf{1 0}]}$ \\
\hline $\mathbf{1 9}$ & 100 & 100 \\
\hline $\mathbf{1 2 . 5}$ & 93.4 & $90-100$ \\
\hline $\mathbf{9 . 5}$ & 74.2 & $50-85$ \\
\hline $\mathbf{4 . 7 5}$ & 4 & $0-10$ \\
\hline
\end{tabular}

* Test was conducted by the researcher at University of Technology laboratory 
TABLE V: Physical and chemical properties of coarse aggregate*

\begin{tabular}{lcc}
\hline \hline Physical Properties & TestResults & IQS 45/1984 ${ }^{[10]}$ \\
\hline Specific Gravity & 2.6 & - \\
\hline Sulfate Content So (\%weight) $_{\text {Materials finer than } 75 \mu m \text { (\% weight) }}$ & 0.04 & $\leq 0.1$ \\
\hline Absorption \% & 0.6 & $3 \%$ Max. \\
\hline
\end{tabular}

* Tests were conducted by the National Center for Construction Laboratories

TABLE VI: Fine aggregate Gradation*

\begin{tabular}{lcc}
\hline \hline Sieve Size & \% passing & IQS 45/1984 Zone(2) ${ }^{[10]}$ \\
\hline $\mathbf{9 . 5} \mathbf{~} \mathbf{m}$ & 100 & 100 \\
\hline $\mathbf{4 . 7 5} \mathbf{~ m m}$ & 96 & $90-100$ \\
\hline $\mathbf{2 . 3 6} \mathbf{~ m m}$ & 89 & $75-100$ \\
\hline $\mathbf{1 . 1 8} \mathbf{~ m m}$ & 74 & $55-90$ \\
\hline $\mathbf{6 0 0} \boldsymbol{\mu m}$ & 47 & $35-59$ \\
\hline $\mathbf{3 0 0} \boldsymbol{\mu m}$ & 23 & $8-30$ \\
\hline $\mathbf{1 5 0} \boldsymbol{\mu m}$ & 5.5 & $0-10$ \\
\hline
\end{tabular}

* Tests were conducted by the National Center for Construction Laboratories

TABLE VII: Physical and chemical properties of fine aggregate*

\begin{tabular}{lcc}
\hline \hline Physical Properties & Test Results & IQS 45/1984 Zone \\
\hline Specific Gravity & 2.51 & - \\
\hline Sulfate Content So3 (\% weight) & 0.23 & $\leq 0.5$ \\
\hline Materials finer than 75 $\mu$ m (\% weight) & $1 . \wedge$ & $5 \%$ Max. \\
\hline
\end{tabular}

* Tests were conducted by the National Center for Construction Laboratories

TABLE VIII: Tests results of steel bars

\begin{tabular}{lcccc}
\hline \hline $\begin{array}{c}\text { Bar Dia. } \\
(\mathbf{m m})\end{array}$ & $\begin{array}{c}\text { Average } \\
\text { NominalBar } \\
\text { Dia.(mm) }\end{array}$ & $\begin{array}{c}\text { Average Yield } \\
\text { Strength }\left(\boldsymbol{f}_{\boldsymbol{y}}\right) \\
(\mathbf{M P a})\end{array}$ & $\begin{array}{c}\text { Average ultimate } \\
\text { Strength }\left(\boldsymbol{f}_{\boldsymbol{u}}\right) \\
(\mathbf{M P a})\end{array}$ & $\begin{array}{c}\text { Average } \\
\text { Elongation } \\
(\mathbf{\%})\end{array}$ \\
\hline $\boldsymbol{6}$ & 6.08 & 490.6 & 539 & 5.13 \\
\hline $\boldsymbol{A S T M}$ A1064/A1064M-14 [13] & $\geq 420$ & -- & $\geq 4.5$ \\
\hline $\boldsymbol{1 6}$ & 15.93 & 544.3 & 661 & 15.6 \\
\hline ASTM $\boldsymbol{A 6 1 5 / 6 1 5 M - 1 4 [ 1 4 ]}$ & $\geq 420$ & $\geq 620$ & $\geq 9$ \\
\hline
\end{tabular}

TABLE IX: SCC mix proportions

\begin{tabular}{|c|c|c|c|c|c|c|c|}
\hline $\begin{array}{l}\text { Trial } \\
\text { No. }\end{array}$ & $\begin{array}{l}\text { Cement } \\
(\mathrm{kg} / \mathrm{m3})\end{array}$ & $\begin{array}{c}\text { Water } \\
\left(\mathrm{kg} / \mathrm{m}^{3}\right)\end{array}$ & $\begin{array}{l}\text { W/pBy } \\
\text { weight }\end{array}$ & $\begin{array}{c}\text { Silica } \\
\text { fume } \\
\left(\mathbf{k g} / \mathbf{m}^{3}\right)\end{array}$ & $\begin{array}{c}\text { Coarse } \\
\text { aggregate } \\
(\mathrm{kg} / \mathrm{m} 3)\end{array}$ & $\begin{array}{c}\text { Fine } \\
\text { aggregate } \\
(\mathbf{k g} / \mathbf{m} 3)\end{array}$ & $\begin{array}{c}\text { Super } \\
\text { plasticizer } \\
(\mathrm{kg} / \mathrm{m} 3)\end{array}$ \\
\hline 6 & 480 & 185 & 0.352 & 45 & 675 & 925 & 11 \\
\hline
\end{tabular}

TABLE X: Fresh SCC tests results

\begin{tabular}{lccc}
\hline \hline Test method & Result & EFNARC (2002)Limits & ACI 237R-07Limits $^{[3]}$ \\
\hline Slump flow(mm) & $710 \mathrm{~mm}$ & $650-800$ & $450-760$ \\
\hline T500 (sec) & $4.2 \mathrm{Sec}$ & $2-5$ & $2-5$ \\
\hline L-box (H2/H1) & 0.95 & $0.8-1$ & $0.8-1$ \\
\hline V-funnel flow time(sec) & $7 \mathrm{Sec}$ & $6-12$ & - \\
\hline J-Ring & $700 \mathrm{~mm}$ & - & $450-760$ \\
\hline Sieve Segregation & $7.135 \%$ & $\leq 15$ & - \\
\hline
\end{tabular}




\section{MiXing AND PRODUCTION OF FRESH SCC}

Self-consolidating concrete used for casting all the deep beams specimens and control samples was mixed and produced in the structural laboratory of Civil Engineering Department, University of Technology using two drum mixers $0.1 \mathrm{~m}^{3}$ capacities for each one. The mixer is cleaned before and after the casting process so that it is water-free. All materials (cement, sand, gravel, silica fume, water, and super plasticizer) are quantified and weighed before the operation of the mixer in each deep beam casting process.

The remaining quantity of fresh SCC was used for casting the control samples. Two standard prisms of $100 \times 100 \times 400 \mathrm{~mm}$, three standard cylinders of $150 \times 300 \mathrm{~mm}$, and three standard cylinders of $100 \times 200 \mathrm{~mm}$ are also cast without any vibration and covering them with nylon sheet to prevent or reduce water evaporation, as shown in Plate 1. After 24-48 hours all the molds of the control samples and the beam were opened. The control samples was cured for 28 days in water tanks while the deep beam specimens were cured by covering with canvas sheet and spraying the water on the canvas sheet twice a day for 56 days.

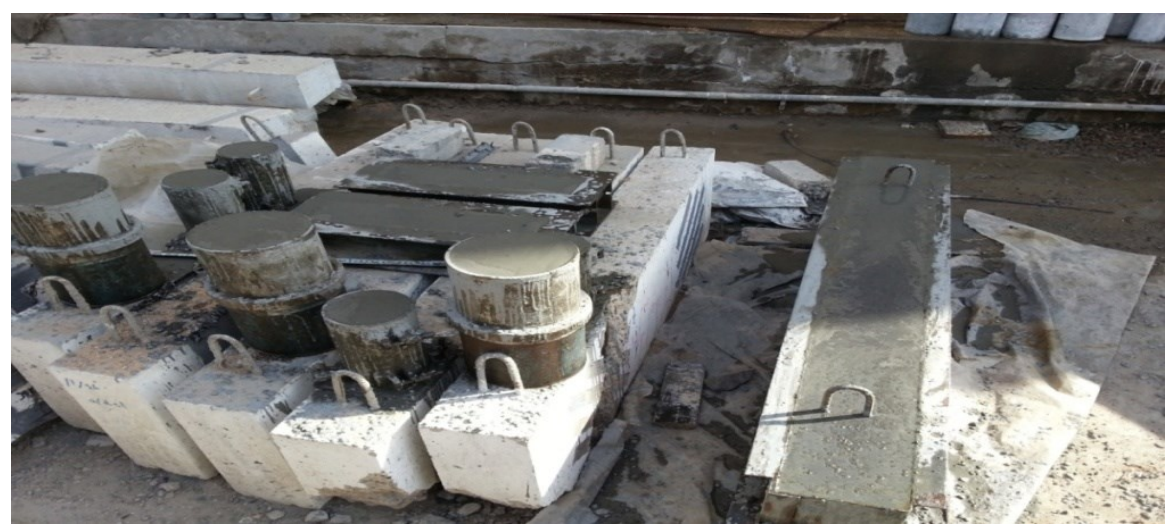

Plate 1: Deep beam specimens and control specimens after finished casting process

\section{Results OF CONTROL SAMPleS}

\section{Compressive Strength Test $\left(\boldsymbol{f}_{c}^{\prime}\right)$}

Compressive strength test of hardened SCC samples (24 standard cylinders) at 7 and 28 days age was performed using the digital testing machine of $4000 \mathrm{kN}$ capacity "CONTROLS" available in the laboratory of the Civil Engineering Department, University of Technology and according to ASTM C39/C39M-16 [16]. Each result in Table XI represents the average values of compressive strength for two cylinders, the first cylinder of $150 \times 300 \mathrm{~mm}$ and the second of $100 \times 200 \mathrm{~mm}$.

\section{Splitting Tensile Strength Test $\left(f_{c t}\right)$}

Splitting tensile strength test of hardened SCC samples (12 standard cylinders) at 28 days age was performed using the digital testing machine of $4000 \mathrm{kN}$ capacity "CONTROLS" available in the laboratory of the Civil Engineering Department, University of Technology and according to ASTM C496/C496M-11 [17]. Each result in Table XI represents the average values of splitting tensile strength for two cylinders, the first cylinder of $150 \times 300 \mathrm{~mm}$ and the second of $100 \times 200 \mathrm{~mm}$.

\section{Flexural strength Test $\left(f_{r}\right)$}

Flexural strength test of hardened SCC samples (12 standard prisms) at 28 days age was performed using the digital testing machine of $3000 \mathrm{kN}$ capacity "ELE" available in the laboratory of the Civil Engineering Department, University of Technology and according to ASTM C78/C78M-16 [18]. Each result in Table XI represents the average values of flexural strength test (modulus of rupture) for two standard prisms of $100 \times 100 \times 400 \mathrm{~mm}$. 
TABLE XI: Experimental results of hardened SCC samples

\begin{tabular}{ccccc}
\hline \hline $\begin{array}{c}\text { Deep beam } \\
\text { Symbol }\end{array}$ & \multicolumn{2}{c}{$\begin{array}{c}\text { Compressive strength } \\
\left(\mathbf{f}_{\mathbf{c}}^{\prime}\right) \mathbf{M P a}\end{array}$} & $\begin{array}{c}\text { Splittingtensile } \\
\text { strength }\left(\boldsymbol{f}_{\boldsymbol{c} t}\right) \\
\mathbf{M P a}\end{array}$ & $\begin{array}{c}\text { Flexural strength } \\
\left(\mathbf{f}_{\mathbf{r}}\right) \mathbf{M P a}\end{array}$ \\
\cline { 2 - 3 } $\boldsymbol{B 1}$ & 32.26 & 42.85 & 4.19 & 4.84 \\
\hline $\boldsymbol{7 d a y s}$ & 30.52 & 42.17 & 4.07 & 5.11 \\
\hline $\boldsymbol{B 3}$ & 31.66 & 41.74 & 3.81 & 5.09 \\
\hline $\boldsymbol{B 4}$ & 33.96 & 48.65 & 3.84 & 5.26 \\
\hline B5 & 32.88 & 45.73 & 4.23 & 5.14 \\
\hline B6 & 34.59 & 46.80 & 3.93 & 5.11 \\
\hline Average & 32.645 & 44.65 & $\varepsilon . \cdot 1$ & 0.9 \\
\hline
\end{tabular}

\section{Casting and Curing Process for SCC Deep Beams SPecimens}

For each casting process for a deep beam, several points should be taken and implemented:

1) The parts of the mold are cleaned, oiled, and fastened together.

2) The reinforcement cage should be placed with its contents (PVC pipes and the additional reinforcement) inside the mold and using plastic spacers to provide the concrete cover from (top, side, and bottom) to specify the effective depth of the deep beam.

3) The mold and all the contents inside it should be placed horizontally and a level.

4) The casting process for all deep beams specimens was done without any kind of vibrations so, the fresh SCC was poured vertically into the mold and filled it normally and passed through the bars and wires of reinforcement without segregation.

\section{INSTRUMENTS AND TESTING PROCEDURE}

Using a calibrated universal testing machine AVERY of $2500 \mathrm{kN}$ capacity all six deep beams specimens were tested by applying hydraulic pressure with two concentrated loads at the laboratory of Civil Engineering Department, the University of Technology. Procedures can be summarized in the following steps:

1) Each beam is coated with white emulsion before the test to detect first crack and cracks propagation.

2) Recording the values of vertical mid-span deflection as a result of increasing the applied loads during the test using a calibrated dial gauge with accuracy of $(0.01 \mathrm{~mm})$ by installing the dial gauge under the mid-span of the beam.

3) Loads are applied in increments of $30 \mathrm{kN}$, deflection measurements are recorded with each load increments until failure.

4) First shear crack load, first flexural crack load, vertical mid span deflection, ultimate failure load, cracks patterns, and failure modes were measured throughout the test time,and marking the locations of the new main cracks that appear with increase in the applied load on the surface of the beam by coloring pen. 


\section{EXPERIMENTAL RESUlts}

\section{Experimental Results for Control Deep Beam}

The control deep beam specimen (B1-Control) was tested to failure without retrofitting. In general, no cracks were noticed in the early stages of loading. The first shear crack was observed at a load of $160 \mathrm{kN}$ with vertical mid-span deflection of $3.65 \mathrm{~mm}$. The first flexural cracks were observed at a load of $180 \mathrm{kN}$ with mid-span deflection of $3.9 \mathrm{~mm}$. The beam failure was at the load $330 \mathrm{kN}$ with mid-span deflection $6.3 \mathrm{~mm}$. Failure mode of the beam was diagonal splitting failure as shown in Plate 2.

\section{Pre-cracking Stage for the deep Beams}

Five beams were tested up to $(60 \%)$ of the average ultimate failure load for control beam, and then released the load. After that the beams were retrofitted by carbon fiber reinforced polymer (CFRP) strips, and then the beams were tested to failure. The beams were tested up to $210 \mathrm{kN}$. Many cracks appeared in beams at pre-cracking stage. It is worth mentioning that, only the main cracks were marked with coloring pen during the tests. Furthermore, most cracks were around or throughout the circular openings. Table XII below presents the values of first shear cracks, first flexural crack, and vertical mid-span deflection for deep beam specimens in second group. After the test finished, the surface of the beam is prepared using the disc and scraper machine, CFRP strips are then bonded and left to dry for a week.

TABLE XII: Experimental results for deep beam specimens

\begin{tabular}{cccccc}
\hline \hline $\begin{array}{c}\text { Specimens } \\
\text { Symbols }\end{array}$ & $\begin{array}{c}\boldsymbol{P}_{\boldsymbol{u}} \\
\mathbf{k N}\end{array}$ & $\begin{array}{c}\boldsymbol{\Delta}(\mathbf{m m}) \mathbf{A t} \\
\mathbf{P}=\mathbf{3 3 0 ~ K N}\end{array}$ & $\mathbf{P}_{\mathbf{c r}}(\mathbf{s h})$ & $\mathbf{P}_{\mathbf{c r}}(\mathbf{f l})$ & $\begin{array}{c}\text { Increase in } \\
\text { Ultimate Load }\end{array}$ \\
\hline $\boldsymbol{B 1 - C o n t r o l}$ & 330 & 6.3 & 160 & 180 & $-\cdots--$ \\
\hline $\boldsymbol{B 1}-\boldsymbol{R}-\boldsymbol{V}$ & 390 & 5.7 & 160 & 160 & $18.2 \%$ \\
\hline $\boldsymbol{B} 2-\boldsymbol{R}-\boldsymbol{H}$ & 420 & 5.45 & 160 & 180 & $27.27 \%$ \\
\hline $\boldsymbol{B 3}-\boldsymbol{R}-\boldsymbol{V H}$ & 420 & 5.4 & 140 & 160 & $27.27 \%$ \\
\hline $\boldsymbol{B} 4-\boldsymbol{R}-\boldsymbol{I}$ & 420 & 5.6 & 140 & 160 & $27.27 \%$ \\
\hline $\boldsymbol{B 5}-\boldsymbol{R}-\boldsymbol{S} \boldsymbol{S}$ & 390 & 5.5 & 160 & 160 & $18.2 \%$ \\
\hline
\end{tabular}

Where: Pu: ultimate failure load, $\Delta$ : mid-span deflection at $330 \mathrm{kN}, \operatorname{Pcr}(\mathrm{sh})$ : first shear crack load, $\operatorname{Pcr}(f 1)$ : first flexural crack load.

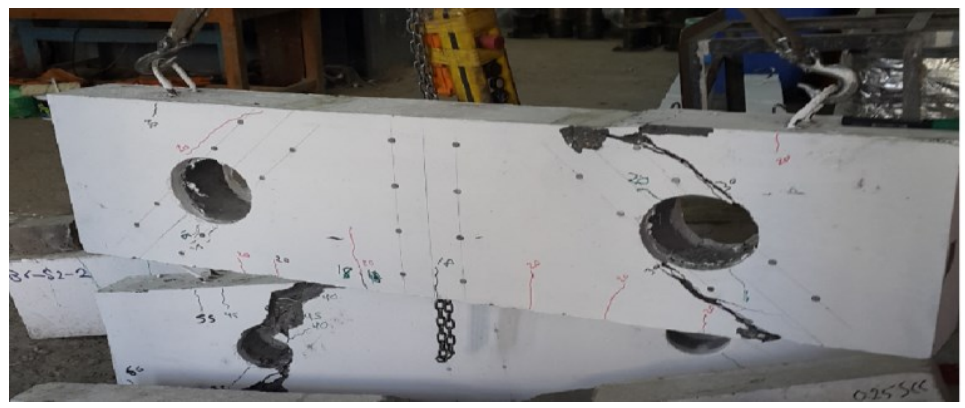

Plate 2: Failure mode and cracks patterns for B1-Control

\section{Experimental Results for the Retrofitted Deep Beams}

The first retrofitted beam B1-R-V was bonded by two vertical strips (U-shape) on the both sides of the circular openings. The width of strips was $100 \mathrm{~mm}$. The first shear cracks and the first flexural cracks were observed at a load of $160 \mathrm{kN}$ with vertical mid-span deflection of $3.5 \mathrm{~mm}$. These cracks propagate and increase in number, width, and length with each further increase of the load. The beam failure was at the load $390 \mathrm{kN}$ with vertical mid-span deflection $6.7 \mathrm{~mm}$. The improvement in load capacity was $18.2 \%$ compared with ultimate failure load of the control beam. Failure mode of the beam was diagonal splitting failure as shown in Plate $r$. 
The second retrofitted beam B2-R-H was bonded by two horizontal strips from top and down sides of the circular openings. The width of strips was $100 \mathrm{~mm}$. The first shear cracks were observed at a load of $160 \mathrm{kN}$ with vertical mid-span deflection of $3.4 \mathrm{~mm}$. The first flexural cracks were observed at a load of $180 \mathrm{kN}$ with mid-span deflection of $3.7 \mathrm{~mm}$. The beam failure was at the load $420 \mathrm{kN}$ with vertical mid-span deflection $6.8 \mathrm{~mm}$. The improvement in load capacity was $27.27 \%$ compared with ultimate failure load of the control beam. Failure mode of the beam was diagonal splitting failure as shown in Plate $\varepsilon$.

The third retrofitted beam B3-R-VH was bonded by two vertical strips (U-shape) on the both sides of the circular openings in addition to two horizontal strips from top and down sides of the circular openings. The width of strips was $100 \mathrm{~mm}$. The first shear cracks were observed at load 140 $\mathrm{kN}$ with vertical mid-span deflection of $3.45 \mathrm{~mm}$. The first flexural cracks were observed at a load of $160 \mathrm{kN}$ with mid-span deflection of $3.8 \mathrm{~mm}$. The beam failure was at the load $420 \mathrm{kN}$ with vertical mid-span deflection $6.7 \mathrm{~mm}$. The improvement in load capacity was $27.27 \%$ compared with ultimate failure load of the control beam. Failure mode of the beam was diagonal splitting failure as shown in Plate ${ }^{\circ}$.

The fourth retrofitted beam B4-R-I was bonded by two inclined carbon fiber (CFRP) strips orthogonal on the load path which linking the load point and support point. The width of strips was $100 \mathrm{~mm}$. The first shear cracks were observed at a load of $140 \mathrm{kN}$ with vertical mid-span deflection of $3.25 \mathrm{~mm}$. The first flexural cracks were observed at a load of $160 \mathrm{kN}$ with mid-span deflection of $3.55 \mathrm{~mm}$. The beam failure was at the load $42 \cdot \mathrm{kN}$ with vertical mid-span deflection $6.6 \mathrm{~mm}$. The improvement in load capacity was $27.27 \%$ compared with ultimate failure load of the control beam. Failure mode of the beam was diagonal splitting failure as shown in Plate 7.

The fifth retrofitted beam B5-R-SS was covered the shear span zone except the opening area by CFRP sheet. The width of the sheet was $350 \mathrm{~mm}$. The first shear cracks and the first flexural cracks were observed at a load of $160 \mathrm{kN}$ with vertical mid-span deflection of $3.45 \mathrm{~mm}$. The beam failure was at the load of $390 \mathrm{kN}$ with vertical mid-span deflection $6.45 \mathrm{~mm}$. The improvement in load capacity was $18.2 \%$ compared with ultimate failure load of the control beam. Failure mode of the beam was diagonal splitting failure as shown in Plate $\mathrm{v}$.

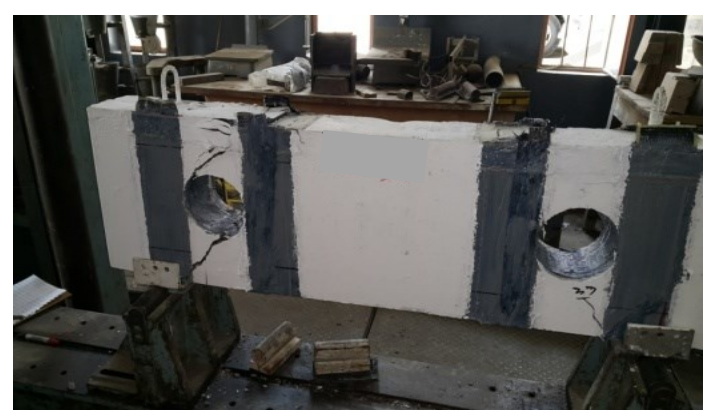

Plate 3: Failure mode and cracks patterns for B1-R-V
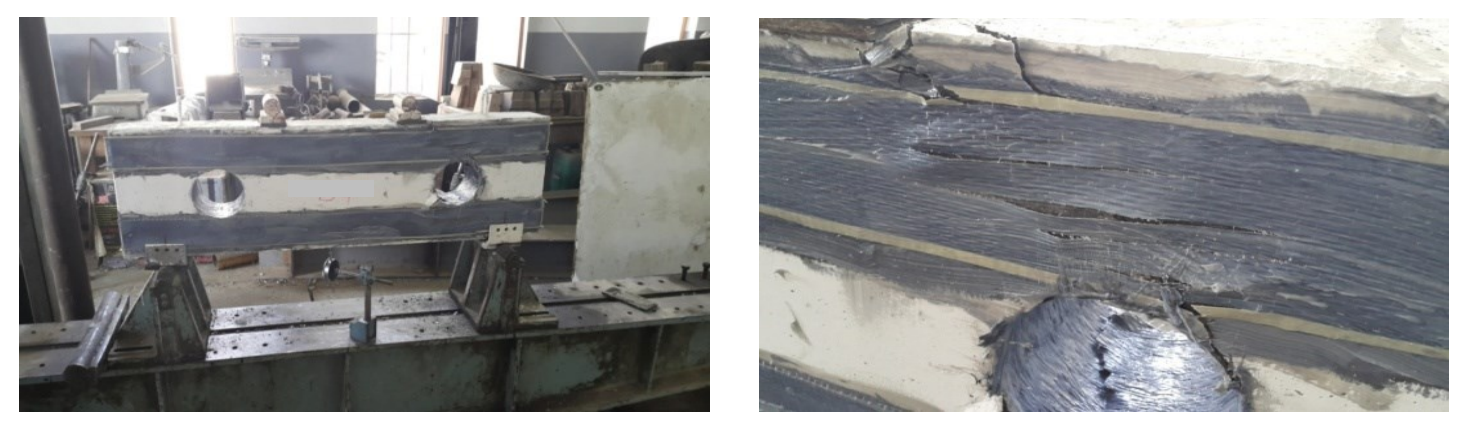

Plate 4: Failure mode and tearing of CFRP strip for B2-R-H 


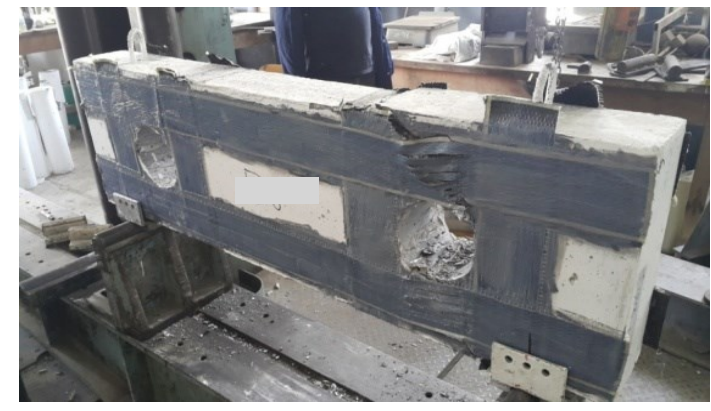

Plate 5: Failure mode and tearing of CFRP strip for B3-R-VH

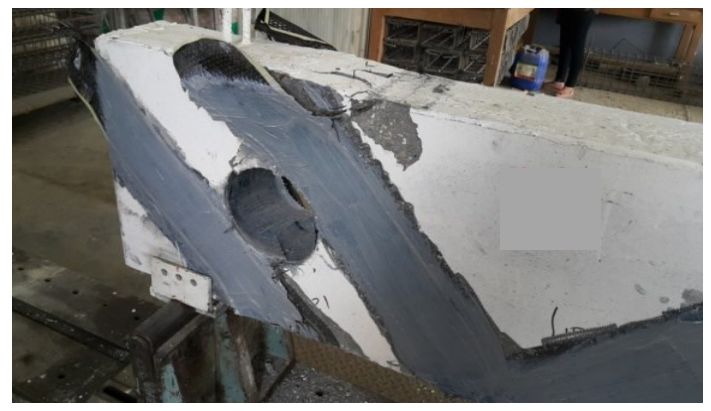

Plate 6: Failure mode and tearing of CFRP strip for B4-R-I

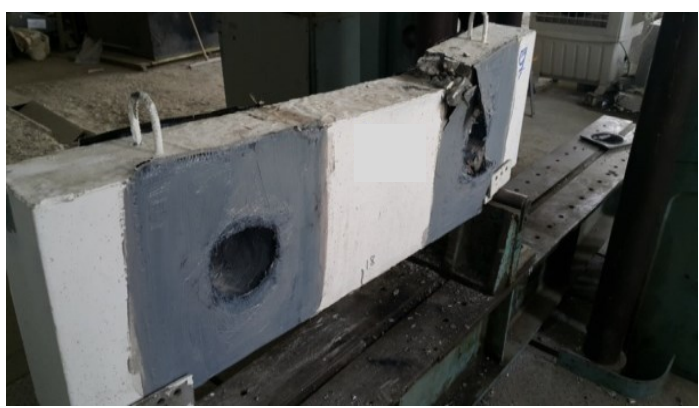

Plate 7: Failure mode and tearing of CFRP strip for B5-R-SS

\section{DISCUSSION OF RESULTS}

1) The appearance, propagations, and numbers of cracks for the retrofitted beams with increased the load was less compared with cracks propagations in non-retrofitted beams (control beams).

2) Carbon fiber (CFRP) strips did not separate from the surface of all the deep beams (debonding) but it were torn apart as shown in Plate 8 .

3) All the tested beams failed in shear failure not flexure failure by propagations of diagonal cracks throughout the opening within the shear span zone.

4) The improvement in the ultimate failure load is achieved due to preventing or restricting the propagations of the cracks as a result of using externally bonded CFRP strips.

5) Figure 3 shows the load-mid-span deflection relationships for the deep beams after retrofitting process. The curves show a clear convergence in the beams performance

6) Failure pattern of the retrofitted beams can be summarized by the following steps:

I. The failure occurred through the opening due to failure of $6 \mathrm{~mm}$ steel reinforcement wire and a loud sound was heard resulting of cutout of steel reinforcement wire as in the case of tensile strength test for steel reinforcement bars.

II. The carbon fiber (CFRP) strips were torn apart.

III. The concrete around the opening was crushed.

7) The tests results show that the deflection values for the retrofitted beams were less than the deflection values for non-retrofitted beam (control beam). Furthermore, the deflection values for any beam from the ten retrofitted beams (B1-R-V, B2-R-H, B3-R-VH, B4-R-I, and B5R-SS) were less than the deflection values for the same beam before the retrofitting in precracking stage as presented in Table XIII below. 


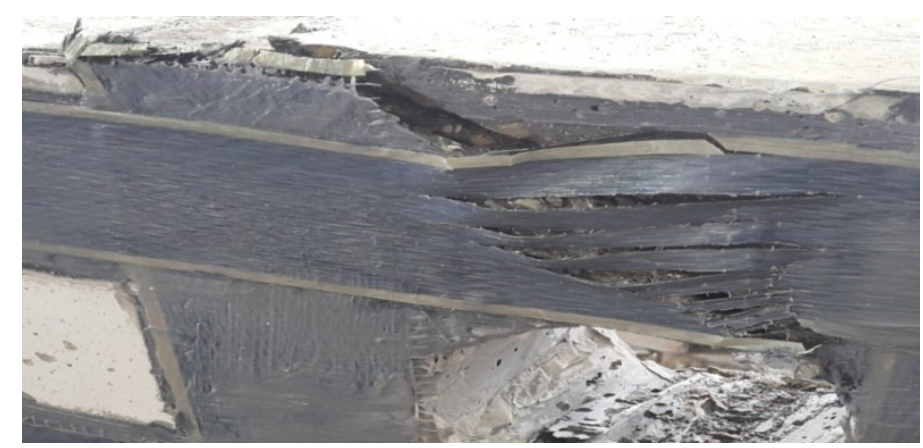

Plate 8: Tearing of CFRP strips

TABLE XIII: Deflection values for the deep beam before and after retrofitting

\begin{tabular}{ccc}
\hline \hline $\begin{array}{c}\text { Specimens } \\
\text { Symbols }\end{array}$ & $\begin{array}{c}\boldsymbol{\Delta}(\mathbf{m m}) \text { Before retrofitted } \\
\text { At } \mathbf{P}=\mathbf{2 1 0 k N}\end{array}$ & $\begin{array}{c}\Delta(\mathbf{m m}) \text { after retrofitted } \\
\text { At } \mathbf{P}=\mathbf{2 1 0 k N}\end{array}$ \\
\hline $\boldsymbol{B} 1-\boldsymbol{R}-\boldsymbol{V}$ & 4.25 & 3.85 \\
\hline $\boldsymbol{B} 2-\boldsymbol{R}-\boldsymbol{H}$ & 4.15 & 3.7 \\
\hline $\boldsymbol{B}-\boldsymbol{R}-\boldsymbol{V} \boldsymbol{H}$ & 4.5 & 4.0 \\
\hline $\boldsymbol{B} 4-\boldsymbol{R}-\boldsymbol{I}$ & 4.3 & 3.9 \\
\hline $\boldsymbol{B} 5-\boldsymbol{R}-\boldsymbol{S S}$ & 4.1 & 3.85 \\
\hline
\end{tabular}

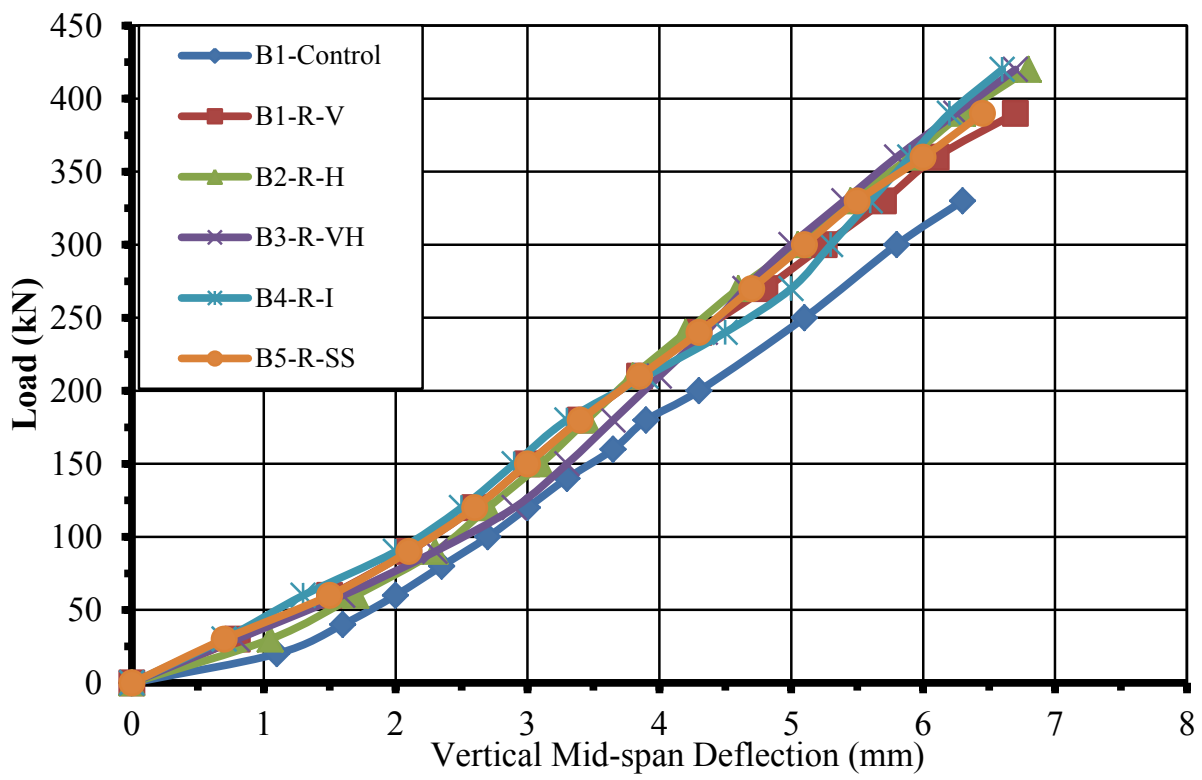

Figure 3: Load- mid-span deflection relationships for deep beams after retrofitting

\section{Conclusions}

Based on the experimental results of the control and retrofitted deep beams, the following conclusions can be drawn:

1) The areas that lie at top and bottom of the openings are the areas where the failure is occur, which should be paid attention, focusing on, and retrofitting them significantly. And not the areas that lies on the left and right of the openings.

2) The inclined strips and the combined vertical and horizontal strips schemes were the best patterns from the five patterns where the improvement value was $27.27 \%$ more than the ultimate load capacity of the control beams. The strips in this pattern help to prevent or reduce the appearance or propagate of cracks. 
3) The retrofitted beams showed reduction in deflection values about (12-13\%) compared to the control beam. It is worth mentioning that, the reduction did not depend on the layouts or patterns the CFRP strips.

4) The process of retrofitting using carbon fiber CFRP strips is successful and useful because it is easy to implement and light weight and its results are fairly good.

\section{REFRENCES}

[1] ACI Committee 318, "Building Code Requirements for Structural Concrete (ACI 318M-14) and Commentary (ACI 318RM-14)", American Concrete Institute, Farmington Hill, USA, 2014.

[2] EFNARC, "The European Guidelines for Self-Compacting Concrete; Specification, Production and Use",EFNARC, 2005.

[3] ACI Committee 237R, "Self-Consolidating Concrete (ACI 237R-07)", Reported by, Emerging Technology Series, 2007.

[4] K. H. Yang, H. C. Eun, and H. S. Chung, "The Influence of Web Openings on the Structural Behavior of Reinforced High-Strength Concrete Deep Beams", Engineering Structures Journal, Vol. 28, No.13, pp. 1825$1834,2006$.

[5] J. A. Khudair, and R. S. Atea, "Shear Behavior of self Compacting Concrete Deep Beams Strengthened with Carbon Fiber Reinforced Polymer Sheets", International Journal of Engineering Research and Technology, Vol. 4, pp. 187-191, 2015.

[6] F. J. Vecchio, and F. Bucci, "Analysis of repaired reinforced concrete structures", Journal of Structural Engineering, Vol.125, Issue 6, pp. 644-652, 1999.

[7] S. W. Kim, and F. J. Vecchio, "Modeling of shear-critical reinforced concrete structures repaired with fiber-reinforced polymer composites", Journal of Structural Engineering, Vol. 134, Issue 8, pp.1288-1299, 2008.

[8] S. Dirar, J. M. Lees, and C. Morley, "Phased nonlinear finite-element analysis of pre-cracked RC T-beams repaired in shear with CFRP sheets", Journal of Composites for Construction, Vol. 17, Issue 4, pp. 476-487, 2013.

[9] Iraqi Standard Specifications No. 5/1984, "Portland Cement", Central Agency for Standardization and Quality Control, Planning Council, Baghdad, Iraq, 1984, (In Arabic).

[10] Iraqi Standard Specifications No. 45/1984, "Aggregate from Natural Sources for Concrete and Construction",Central Agency for Standardization and Quality Control, Planning Council, Baghdad, Iraq, 1984, (In Arabic).

[11] American Society for Testing and Materials, "Standard Specification for Chemical Admixtures for Concrete", ASTM C494/C494M - 15, USA, 2015

[12] American Society for Testing and Materials, "Standard Test Methods and Definitions for Mechanical Testing of Steel Products", ASTM A370-14, USA, 2014.

[13] American Society for Testing and Materials, "Standard Specification for Carbon-Steel Wire and Welded Wire Reinforcement, Plain and Deformed, for Concrete”,ASTM A1064 / A1064M-14, USA, 2014.

[14] American Society for Testing and Materials, "Standard Specification for Deformed and Plain Carbon-Steel Bars for Concrete Reinforcement", ASTM A615 / A615M-14, USA, 2014.

[15] EFNARC, "Specifications and Guidelines for Self-Compacting Concrete", EFNARC, 2002.

[16] American Society for Testing and Materials, "Standard Test Method for Compressive Strength of Cylindrical Concrete Specimens”,ASTM C39/C39M-16, USA, 2016.

[17] American Society for Testing and Materials, "Standard Test Method for Splitting Tensile Strength of Cylindrical Concrete Specimens”,ASTM C496/C496M-11, USA, 2011.

[18] American Society for Testing and Materials, "Standard Test Method for Flexural Strength of Concrete (Using Simple Beam with Third-Point Loading)", ASTM C78 / C78M-16, USA, 2016. 